\title{
IDENTIFIKASI MANFAAT BISNIS TEKNOLOGI INFORMASI PADA PEMERINTAH DAERAH: STUDI KASUS PROVINSI SULAWESI UTARA
}

\author{
Hans Wowor ${ }^{1)}$, Stanley Karouw ${ }^{2)}$ \\ 1,2 Program Studi Teknik Informatika, Fakultas Teknik, Universitas Sam Ratulangi, \\ Jl. Kampus UNSRAT Bahu, Manado, 95115, Indonesia \\ E-mail: hans.wowor@unsrat.ac.id ${ }^{1}$, stanley.karouw@unsrat.ac.id ${ }^{2}$
}

\begin{abstract}
North Sulawesi province is fostering regional development towards a society which have values, prosperous and competitive cultures. Information Technology (IT) have become a key enabler to accelerate region developments. To optimize IT utilization, local government using IT Blueprint as a general guidelines for conduct IT investing. This paper will show that by using Ranti's IS/IT Generic Business Value, all IT Business Value can be quantified in reasonable and responsible manner. This paper also proposed complete list for IT Business Value Specified for Local Governments.
\end{abstract}

Keywords: IT Investment, IT Business Value, Local Government

\begin{abstract}
Abstrak
Pemerintah provinsi Sulawesi Utara berupaya untuk memacu pembangunan daerah menuju masyarakat yang berbudaya, berdaya saing dan sejahtera. Salah satu faktor penting dalam mendukung akselerasi pembangunan daerah adalah dengan mengoptimalkan pemanfaatan Teknologi Informasi (TI). Untuk mengoptimalkan pemanfaatan TI tersebut, Pemerintah Daerah (Pemda) telah memiliki suatu perencanaan strategis (renstra) TI sebagai pedoman investasi TI berbasis manfaat bisnis. Implementasi investasi TI yang dilakukan Pemda dapat dijustifikasi apabila manfaat bisnis dari implementasi TI tersebut dapat diidentifikasi dengan jelas. Paper ini akan menunjukkan bahwa Metode Ranti's IS/IT Generic Business Value dapat digunakan untuk mengidentifikasi dan mengklasifikasi manfaat bisnis generik TI pada provinsi Sulawesi Utara. Paper ini juga mengusulkan daftar Manfaat Bisnis IT Khusus Pemerintah Daerah.
\end{abstract}

Kata Kunci: Investasi TI, Manfaat Bisnis TI, Pemerintah Daerah

\section{Pendahuluan}

Peranan Teknologi Informasi (TI) dalam mendukung aktivitas bisnis organisasi terasa semakin meluas. TI bukan saja memberikan peningkatan efisiensi dan efektifitas kinerja organisasi namun juga telah menjadi pemberdaya bagi organisasi untuk menjalankan proses bisnisnya dan mencapai tujuan organisasi. Melihat pemanfaatan TI yang semakin meluas tersebut maka Pemerintah, dari tingkat pusat hingga daerah, sebagai suatu organisasi yang berorientasi nir laba, perlu mengoptimalkan pemanfaatan TI dalam mendukung pencapaian tujuan nasional, yakni meningkatkan kesejahteraan rakyat.

Investasi TI yang telah dan akan diimplementasikan oleh setiap Satuan Kerja
Prangkat Daerah (SKPD) di Provinsi Sulawesi Utara, selalu cenderung naik setiap tahun, seperti misalnya yang dilakukan oleh Dinas Pendapatan Daerah provinsi Sulawesi Utara ${ }^{(10)}$. Kenyataan ini merupakan suatu fakta menarik. Investasi TI yang sedemikian besar dan sering dilakukan oleh Dipenda tersebut menunjukkan adanya kesadaran mengenai pentingnya pemanfaatan TI, namun demikian belum ditemukan adanya dokumen hasil analisis manfaat TI yang diperoleh dari investasi TI tersebut.

Permasalahan inilah yang ingin diangkat dalam penelitian ini, yakni bagaimana mengidentifikasi dan mengklasifikasikan manfaat bisnis TI spesifik Pemda dari adanya investasi TI 


\section{Manfaat Bisnis TI}

Manfaat bisnis TI (IT business value $)^{[1][2][3]}$ didefinisikan sebagai manfaat atau hasil yang diperoleh dari suatu investasi TI yang dapat meningkatkan kinerja organisasi. Pengertian manfaat bisnis ini, lebih dari sekedar memberikan benefit atau keuntungan secara finansial saja. Manfaat bisnis didasarkan atas pemikiran bagaimana TI bisa memberikan menjamin efisiensi, efektivitas, meningkatkan produktivitas hingga menciptakan keunggulan kompetitif tertentu bagi organisasi. Pengertian manfaat ini mengikuti pemahaman Parker ${ }^{[4][5]}$, dimana menurut Bannister dan Remenyi ${ }^{[6]}$ didasarkan atas definisi Porter ${ }^{[7]}$ tentang value.

Upaya untuk mengidentifikasi dan mengklasifikasi manfaat bisnis TI telah dilakukan oleh beberapa orang. Parker ${ }^{[4][5]}$ membedakan manfaat bisnis TI menjadi: 1) Manfaat tangible yakni manfaat TI yang mudah diukur; 2). Manfaat intangible; yakni manfaat TI yang sulit untuk diukur; 3). Diantara kedua manfaat tersebut terdapat manfaat quasi-intangible. Remenyi et.al ${ }^{[8]}$ membedakan klasifikasi manfaat bisnis TI menjadi: 1). Easy to quantify (EQT) atau hard benefit; 2). Hard-to-quantify Tangible (HQT); 3). Easy-to-quantify Intangible (EQI); 4). Hard-toquantify Intangible (HQI) atau strategic/soft benefit. Perlu dicermati bahwa, usaha mengidentifikasi dan mengklasifikasikan manfaat bisnis TI tersebut diatas dilakukan berdasarkan pendekatan positivist-methodology. Menurut Bannister dan Remenyi ${ }^{[6]}$, selain menggunakan pendekatan diatas, identifikasi dan klasifikasi manfaat bisnis TI, dapat juga dilakukan berdasarkan pendekatan hermeneutic. Proses identifikasi dan klasifikasi dengan menggunakan pendekatan hermeneutic ini dilakukan oleh Ranti $^{[1][2]}$

Menurut hasil penelitian yang dilakukan Ranti $^{[1]}$, dengan mengambil studi kasus di Indonesia, maka terdapat 13 kategori dan 73 subkategori manfaat bisnis TI. Jika dibandingkan dengan beberapa negara berkembang lainnya, maka terdapat 3 manfaat bisnis TI yang unik untuk Indonesia. Ketiga manfaat bisnis TI itu adalah: 1). (Reducing cost of) subscription cost selected reading materials or subscription cost per employee, dapat diartikan sebagai pengurangan biaya berlangganan untuk materi bacaan tertentu (misalnya koran atau majalah elektronik) atau biaya langganan setiap karyawan. 2) (Increasing image caused by) complying with regulations, yang dapat diartikan sebagai memperkuat image suatu organisasi karena turut mematuhi aturan-aturan tertentu, yang mengikat organisasi tersebut. 3)(Increasing image caused by) using branded system, yang dapat diartikan sebagai meningkatkan image organisasi karena menggunakan suatu aplikasi tertentu yang terkenal. Manfaat bisnis TI generik hasil penelitian Ranti ${ }^{[1]}$ selengkapnya dapat dilihat pada Gbr. 1 dibawah ini:

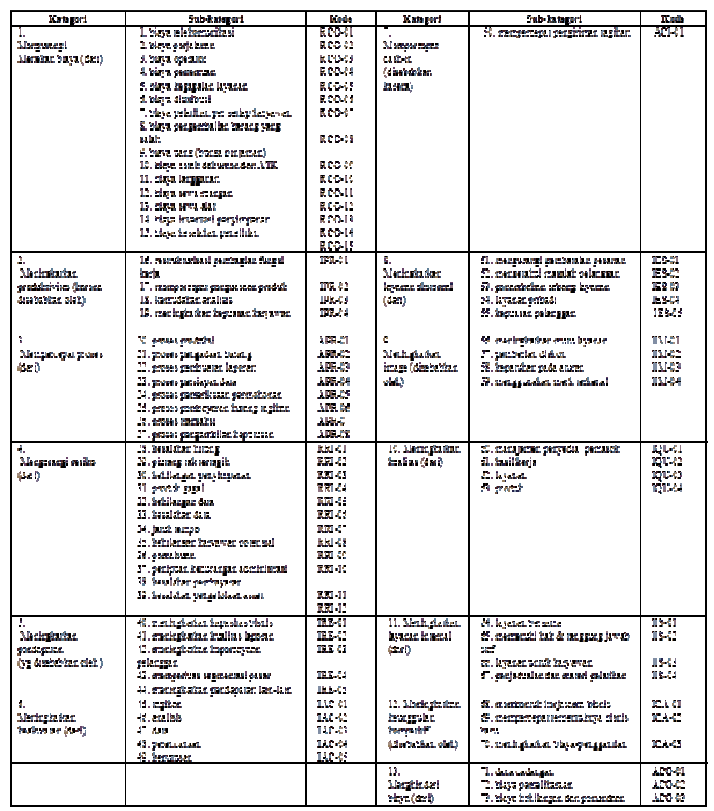

Gbr. 1. Manfaat Bisnis TI menrut Ranti ${ }^{[1]}$

\section{Metodologi Pemecahan Masalah}

Penelitian yang dilakukan bersifat studi kasus. Obyek studi kasus adalah beberapa Satuan Kerja Perangkat Daerah (SKPD) yang tersebar di Provinsi Sulawesi Utara, seperti Kantor Gubernur Sekretariat Daerah Provinsi Sulawesi Utara, Dinas Pendapatan Daerah (DIPENDA) Sulawesi Utara dan seluruh UPTD Dipenda di 15 kabupaten/kota, Sekretaris Dewan Perwakilan Rakyat Daerah Provinsi Sulawesi Utara dan Kota Manado, Badan Perencanaan dan Pengawasan Pembangunan Daerah (BAPPEDA) Provinsi Sulawesi Utara dan Kota Manado, Dinas Pariwisata Provinsi Sulawesi Utara dan Kota Manado, Dinas Perhubungan, Komunikasi dan Informatika Kota Tomohon.

Untuk keperluan pengumpulan data, dilakukan dengan cara:

1). Menyebarkan kuesioner;

2) Melakukan wawancara;

3) Melakukan diskusi kelompok;

4) Melakukan studi pustaka.

Data yang ditemukan dikaji secara kualitatif berdasarkan metode hermeneutics. Langkahlangkah pemecahan masalah, akan mengikuti kerangka kerja BVP (Be Vissta Planning $)^{[9]}$. 
Asumsi yang digunakan adalah Provinsi Sulawesi Utara telah memiliki Renstra TI dan telah memiliki usulan potensi strategi.

\section{Pembahasan}

Provinsi Sulawesi Utara telah memiliki renstra $\mathrm{TI}^{[9][10]}$. Adapun renstra TI tersebut berisi potensi strategi TI yang akan diimplementasikan dalam kurun waktu 3 (tiga) hingga 5 (lima) tahun kedepan.

Potensi strategi TI yang akan diimplementasikan tersebut adalah ${ }^{[8][9]}$ :

1). Aplikasi Bisnis, yakni strategi TI yang mendukung pelaksanaan fungsi kelembagaan pemerintahan, diantaranya adalah: Official Website, Aplikasi e-Learning, Aplikasi Forum Diskusi, Aplikasi Knowledge Management System, Aplikasi Laporan Kinerja Aparatur, Aplikasi Laporan Keuangan, Aplikasi Internal Kontrol, Aplikasi e-procurement, Aplikasi Laporan Penerimaan PAD Berkala (Harian, Mingguan, Bulanan dan Tahunan), Aplikasi Help Desk Service, Aplikasi e-mail, Aplikasi chat messenger, Aplikasi SMS Gateway, Aplikasi Payment Gateway, Aplikasi e-CRM, Aplikasi Sistem Komputerisasi Terintegrasi.

2) Basis data dan infrastruktur jaringan yakni web database dan server database dan infrastruktur jaringan untuk komunikasi data. Infrastruktur jaringan bersifat LAN, intranet dan ekstranet.

Potensi strategi TI ini dapat dilihat pada Gbr. 2 berikut ini.

Proses identifikasi manfaat bisnis TI diawali dengan wawancara, kuesioner dan diskusi kelompok. Penulis melakukan penafsiran dari data yang diperoleh berdasarkan pengakuan nara sumber, responden dan peserta diskusi kelompok.

Berdasarkan masukan-masukan tersebut diatas maka dapat disimpulkan bahwa usulan potensi strategi TI memiliki manfaat bisnis sebagai berikut:

1) Mengurangi penggunaan telepon pribadi;

2) Beberapa proses kerja dapat dilakukan oleh seorang pegawai;

3) Proses pengurusan berkas lebih cepat;

4) Mempercepat proses pembuatan laporan harian, mingguan, bulanan, triwulan, semester dan tahunan;

5) Wajib pajak/penyetor retribusi dapat lebih cepat membayar nilai pajak/retribusi;

6) Pimpinan dan aparatur bisa lebih cepat dan lebih akurat mengambil keputusan dalam perencanaan, penetapan dan evaluasi PAD;

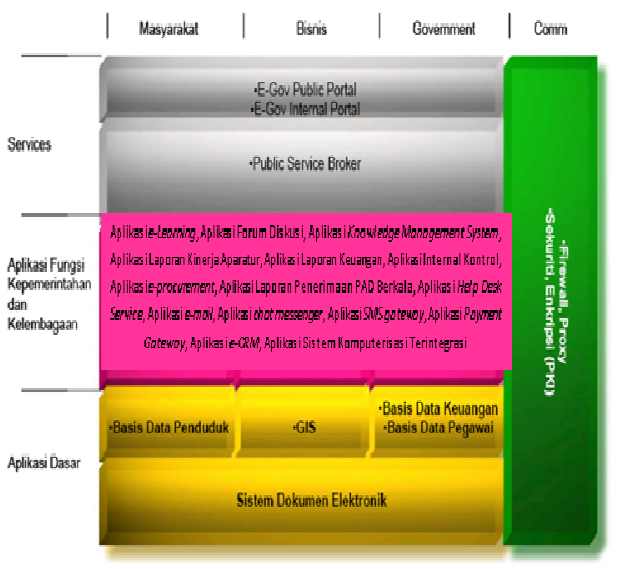

Gbr. 2. Potensi Strategi TI Provinsi Sulawesi Utara

7) Mengurangi kesalahan hitung dari aparatur;

8) Mengurangi terjadinya kehilangan data;

9) Mengurangi terjadinya kesalahan data wajib pajak/penyetor retribusi dan data hasil penerimaan PAD;

10) Menghindari terjadinya pemalsuan data oleh aparatur;

11) Menghindari terjadinya penipuan/kecurangan administrasi oleh aparatur;

12) Mengurangi kesalahan pembayaran oleh wajib pajak/penyetor retribusi;

13) Wajib pajak/penyetor retribusi merasa lebih yakin dengan nilai pajak yang harus dibayar;

14) Wajib pajak/penyetor retribusi merasa lebih puas dengan pelayanan yang diberikan;

15) Dapat mengetahui dan memahami masalah wajib pajak/penyetor retribusi; 16) Meningkatkan image aparatur karena kualitas pelayanan;

17) Meningkatkan kualitas kerja apartur;

18) Meningkatkan image aparatur karena menggunakan merk terkenal dan kepatuhan pada aturan.

Hasil manfaat bisnis TI ini, jika dipetakan pada Ranti's Generic IS/IT Business Value ${ }^{[1]}$ akan seperti Gbr. 3 dibawah.

Analisis manfaat bisnis TI dari Gbr. 3 secara detail dapat diterangkan sebagai berikut:

1. Reducing Cost (RCO).

Bisnis proses pengelolaan PAD merupakan suatu proses yang dinamis. Menekan biaya merupakan salah satu manfaat yang bisa diperoleh dari implementasi SI/TI. RCO yang teridentifikasi adalah:

a. Mengurangi biaya telekomunikasi (RCO01); implementasi jaringan intranet dan aplikasi laporan berkala akan dapat menekan biaya telekomunikasi diantara Dipenda dan instansi/badan/dinas yang terkait. 


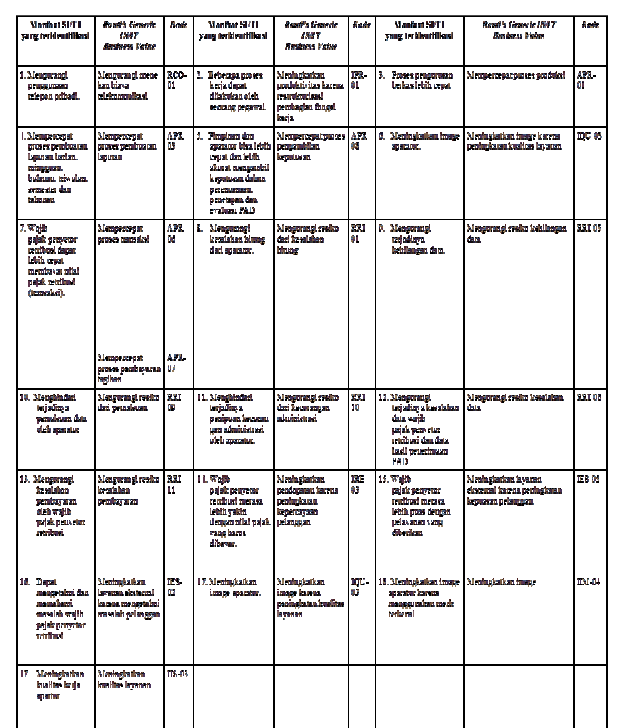

Gbr. 3. Manfaat Bisnis TI yang teridentifikasi.

2. Increasing Productivity (IPR).

Peningkatan produktivitas berkaitan dengan mengoptimalkan sumber daya manusia. Implementasi SI/TI memberikan manfaat berupa:

a. Meningkatkan produktivitas karena restrukturisasi pembagian fungsi kerja (IPR-01); aplikasi sistem komputerisasi terintegrasi memungkinkan beberapa sub proses bisnis PAD, dikerjakan oleh satu pegawai.

3. Accelerating Process (APR).

Implementasi SI/TI memberikan manfaat mempercepat proses dalam hal:

a. Mempercepat proses produksi (APR-01); aplikasi sistem komputerisasi terintegrasi, basis data inventory akan mampu mempercepat pengolahan data (penerimaan, pendaftaran, penetapan dan pencetakan) wajib pajak/penyetor retribusi oleh aparatur. Bukti pembayaran akan lebih cepat diserahkan kepada wajib pajak/penyetor retribusi.

b. Mempercepat proses transaksi (APR-06 dan APR-07); aplikasi payment gateway akan dapat mempercepat pembayaran nilai pajak oleh wajib pajak/penyetor retribusi.

c. Mempercepat proses pembuatan laporan (APR-03); aplikasi Laporan Berkala (aplikasi laporan penerimaan dan pelaksanaan pemungutan PAD) akan membantu aparatur untuk menyelesaikan laporan penerimaan PAD.

4. Reducing Risk (RRI).

Implementasi SI/TI dapat memberikan manfaat seperti: a. Mengurangi resiko kesalahan hitung (RRI-01); penggunaan aplikasi sistem komputerisasi terintegrasi dan aplikasi laporan berkala akan mengurangi terjadinya kesalahan hitung aparatur pada proses penetapan nilai pajak yang harus dibayar.

b. Mengurangi resiko kehilangan data (RRI-05); implementasi basis data inventory merupakan solusi untuk mengurangi resiko kehilangan data.

c. Mengurangi resiko kesalahan data (RRI06); implementasi basis data inventory dan aplikasi laporan berkala yang standar antara Dipenda, UPTD, dan instansi/badan/dinas terkait dapat mengurangi resiko kesalahan data.

d. Mengurangi resiko dari pemalsuan (RRI09); implementasi aplikasi laporan keuangan, aplikasi internal kontrol, aplikasi laporan penerimaan dan pelaksanaan pemungutan PAD dapat mengurangi terjadinya pemalsuan data atau laporan.

e. Mengurangi resiko dari kecurangan administrasi (RRI-10). Tindakan kecurangan administrasi bisa dihindari dengan adanya aplikasi Laporan Penerimaan PAD, aplikasi internal kontrol dan aplikasi e-procurement.

f. Mengurangi resiko kesalahan pembayaran (RRI-11). Kesalahan pembayaran dapat terhindarkan dengan implementasi aplikasi laporan penerimaan dan pelaksanaan pemungutan PAD dan aplikasi sistem komputerisasi terintegrasi.

5. Increasing Revenue (IRE).

Implementasi SI/TI memberikan manfaat peningkatan pendapatan dengan cara:

a. Meningkatkan revenue karena peningkatan kepercayaan wajib pajak dan penyetor retribusi (IRE-03).

6. Increasing External Services (IES).

Peningkatan layanan eksternal tersebut berupa:

a. Meningkatkan layanan eksternal karena mengetahui masalah wajib pajak/penyetor retribusi (IES-02). Masalah wajib pajak/penyetor retribusi dapat diketahui dengan menggunakan Aplikasi e-mail, Aplikasi chat messenger, Aplikasi Help Desk Services.

b. Meningkatkan layanan eksternal karena adanya kepuasan pelanggan (IES-05). Kepuasan wajib pajak/penyetor retribusi merupakan salah satu faktor sukses terpenting yang harus dioptimalkan. Aplikasi e-CRM dan aplikasi Help Desk 
Services akan membantu Dipenda dalam meningkatkan kepuasaan wajib pajak/penyetor retribusi.

7. Increasing Quality (IQU).

Peningkatan kualitas menjadi tujuan yang ingin dicapai oleh Dipenda. Peningkatan kualitas ini dapat dicapai dengan:

a. Meningkatkan kualitas dari layanan (IQU-

03). Implementasi aplikasi sistem komputerisasi terintegrasi akan meningkatkan kualitas layanan kepada wajib pajak. Aplikasi e-CRM akan menunjukkan layanan Dipenda yang berkelas.

8. Increasing Internal Services (IIS).

Implementasi SI/TI dapat meningkatkan layanan internal dengan cara:

a. Meningkatkan layanan internal (IIS-03). Aplikasi Laporan Kinerja, akan membantu para staf untuk tetap termotivasi dalam melakukan tugas. Aplikasi ini akan mencakup perhitungan kerja lembur. Begitu juga dengan aplikasi knowledge management system, aplikasi forum diskusi dan aplikasi e-Learning akan membantu aparatur untuk menguasai setiap aplikasi yang ada dan menyelesaikan masalah-masalah yang timbul dalam operasional sehari-hari.

9. Increasing image (IIM) caused by using branded system, yang dapat diartikan sebagai meningkatkan image organisasi karena menggunakan suatu aplikasi tertentu yang terkenal dan karena kepatuhan pada aturan.

Secara umum, diagram manfaat bisnis TI Provinsi Sulawesi Utara dapat dilihat pada Gbr. 4 berikut

\section{Kesimpulan}

Kesimpulan dari penelitian ini adalah:

1. Tabel Ranti's Generic IS/IT Business Value dapat digunakan untuk mengidentifikasi manfaat bisnis TI yang ada pada Pemerintah Daerah. Pemetaan manfaat bisnis TI pada Tabel Ranti's Generic IS/IT Business Value juga dapat mengklasifikasi manfaat bisnis berdasarkan kategori spesifik tertentu, dalam hal ini adalah kategori yang spesifik untuk organisasi nir laba, seperti Pemerintah Daerah.

2. Tabel Ranti's Generic IS/IT Business Value tersebut dapat juga digunakan menjadi instrumen kuesioner guna memudahkan responden dalam mengenali manfaat bisnis TI. Tentu saja, perlu dilakukan penyesuaian seperlunya sesuai kebutuhan penggunaannya.

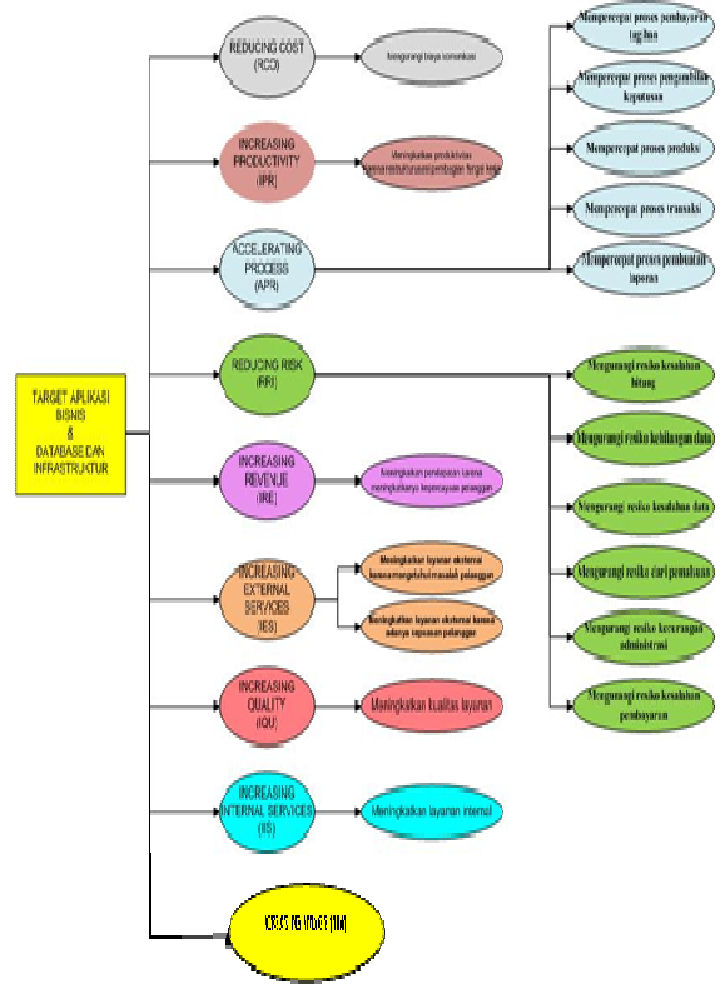

Gbr. 4. Diagram Manfaat Bisnis TI Provinsi Sulawesi Utara

3. Model manfaat bisnis TI Pemda tingkat provinsi adalah mempercepat proses (APR), mengurangi resiko (IRR), mengurangi biaya (RCO), meningkatkan produktivitas (IPR), meningkatkan pendapatan (IRE), meningkatkan layanan eksternal (IES), meningkatkan kualitas (IQU) dan meningkatkan kualitas dari layanan internal (IIS). Manfaat bisnis APR merupakan manfaat bisnis yang paling sering disebut sedangkan manfaat bisnis IRR merupakan manfaat bisnis yang paling banyak memiliki sub-kategori manfaat bisnis.

4. Manfaat bisnis TI unik di Indonesia, juga teridentifikasi pada organisasi nir laba seperti Pemerintah Daerah, yakni Increasing image (IIM) caused by menggunakan merk terkenal dan kepatuhan pada aturan.

\section{Referensi}

[1] Ranti, B. (2008). Identification of Information Systems/Information Technology Business Values with Hermeneutic Approach: Cases in Indonesia. Ph.D Thesis. Fakultas Ilmu Komputer, Universitas Indonesia.

[2] Ranti, B. (2006). Identifying of Businees Value of Information Technology using Hermeneutics. Workshop Prosiding, MoMM 2006 \& iiWASS 2006, p.695-699. 
[3] Ranti, B. (2006). A Review of Information Technology Investment Evalution Methodologies: The Need for Approriate Evaluation Methods. Paper, Konferensi Nasional Teknologi Informasi dan Komunikasi Untuk Indonesia, ITB.

[4] Parker, M. (1988). Information Economics: Linking Business Performance to Information Technology. Prentice Hall, New Jersey.

[5] Parker, M. (1996). Strategic Transformation and Information Technology; Paradigm for Performing while Transforming. Prentice Hall, New Jersey.

[6] Bannister, F. Remenyi, D. (1999). Instinct and Value in IT Decision. Occasional Paper Series. Management Research Center, Wolverhampton Business School, University of Wolverhampton.

[7] Porter, M. E. (2008). On Competition. Harvard Business School Publishing Corp, Massachuttes-USA.

[8] Remenyi, D., Arthur, A., Sherwood-Smith, M. (2000), The Effective Measurement and Management of IT Costs and Benefits, $2^{\text {nd }}$ Edition, Elsevier.

[9] Stanley Karouw. (2011). Perencana Strategis Sistem Informasi/Teknologi Informasi berbasis Manfaat Bisnis TI dengan menggunakan Metodologi Be Vissta Planning Studi Kasus Dinas Pendapatan Daerah Sulawesi Utara., Paper Ilmiah, diterbitkan di Tekno, Edisi Desember 2011, ISSN:

[10]Dinas Pendapatan Daerah Provinsi Sulawesi Utara.(2006). Rencana Strategik Dinas Pendapatan Daerah Provinsi Sulawesi Utara Tahun 2006-2010. 